\section{Биологически активная добавка, молодняк крупного рогатого скота, эффективность кормления, рацион кормления}

Biologically active supplement, young cattle, feeding efficiency, diet

\title{
ЭФФЕКТИВНОСТЬ ВЛИЯНИЯ БИОЛОГИЧЕСКИ АКТИВНОЙ ДОБАВКИ НА РОСТ И РАЗВИТИЕ ТЕЛЯТ
}

\author{
А.И. Фролов (фото) \\ к.С.-х.Н., ведущий научный сотрудник лаборатории \\ технологии производства молока и говядины \\ А.Н. Бетин \\ к.С.-Х.Н., ведущий научный сотрудник лаборатории \\ технологии производства свинины \\ ФГБНУ «Всероссийский научно-исследовательский институт \\ использования техники и нефтепродуктов в сельском \\ хозяйстве», г. Тамбов
}

При изучении обмена веществ у животных зачастую обнаруживается дефицит в их организме микроэлементов. Рационы, сбалансированные по валовому содержанию минеральных веществ, существенно различаются по биологическому действию на организм животного. Это связано с тем, что не все минеральные вещества находятся в одинаково доступной форме [1]. Восполнить их потерю одними только кормовыми средствами проблематично. Даже введением премиксов в рацион не удаётся в полной мере удовлетворить потребность животных в минеральных веществах, так как в состав премиксов входит ограниченное количество солей микроэлементов (6-8). Животные требовательны к количественному составу и балансу микроэлементов в рационе, и субклинический дефицит приводит к значительным экономическим потерям из-за снижения эффективности производства продукции. Телёнок, переболевший в 3-5-дневном возрасте диспепсией, недодаст, став коровой, от 500 до 1500 л молока за лактацию, какие бы идеальные условия кормления и содержания ей не создавали, так как в результате «адаптации» к дефициту микроэлементов нарушается обмен и синтез нуклеиновых кислот и падает генетически запрограммированный, определённый породными особенностями потенциал высокой продуктивности как у взрослых животных, так и у полученного от них молодняка [2]. 
Дефицит микроэлементов в кормовых растениях, недостаточное поступление их в организм вызывает патологическое состояние - комплексные гипомикроэлементозы, что вызывает торможение роста и развития животных, отрицательно сказывается на их продуктивности и воспроизводительной функции. В настоящее время актуальными являются разработка и внедрение в технологию кормления сельскохозяйственных животных наиболее эффективных препаратов с необходимыми биологически активными веществами.

Научная новизна. Впервые, на основании исследования, дано практическое обоснование использования в технологии кормления молодняка крупного рогатого скота отечественной кормовой добавки на основе микроэлементов в виде гидроксид полимальтозных и хелатных комплексов. В состав добавки входят медь, кобальт, селен, йод, марганец в виде амминоатов, цинк в хелатной форме глюконата, а также гидролизат растительного белка [3]. Установлено её положительное действие на организм в целом, функции различных органов и систем животных и птицы $[4,5]$. Экспериментально доказана эффективность её применения для оптимизации обменных процессов. Производитель - ООО «А-БИО».

Задача исследований - повышение экономической эффективности кормления молодняка крупного рогатого скота с использованием в рационах новой отечественной кормовой добавки с целью получения здоровых животных с высокой продуктивностью.

\section{Методы исследования}

Для выполнения поставленной задачи проведён научно-производственный опыт в соответствии с требованиями по подбору аналогов, соблюдения одинаковых условий кормления и содержания животных и учёта результатов [6]. При постановке опыта были использованы 30отехнические, физиологические, клинические, биохимические и другие методы исследований.

Все корма, входящие в состав рационов крупного рогатого скота, подвергали зоотехническому анализу по соответствующим методикам. В цельной крови и сыворотке определяли биохимические показатели, КМАФАнМ в образцах ЖКТ - по общепринятым методикам. Посевы осуществлялись из разведений $10^{-1}-10^{-7}$ в количестве 0,1 мл.

Полученный экспериментальный материал обрабатывали статистически, используя критерий Стьюдента. Результаты рассматривали как достоверные, начиная со значения $\mathrm{P}<0,05$.

\section{Результаты исследования}

Научно-производственный опыт был проведён по следующей схеме (табл. 1).

Кормление молодняка всех групп было одинаковым - по детализированным нормам кормления [7]. Различие в кормлении заключалось в

Таблица 1 - Схема опыта

\begin{tabular}{|l|c|c|}
\hline \multicolumn{1}{|c|}{ Группа } & Количество животных, гол. & Условия опыта \\
\hline Контрольная & 15 & Основной рацион (ОР) \\
\hline Опытная & 15 & $\begin{array}{c}\text { ОР + биодобавка }-1 \text { мл/кг живой массы ежедневно } \\
\text { с молоком с 4-го дня жизни до 60-суточного возраста }\end{array}$ \\
\hline
\end{tabular}

том, что животным опытной группы в молоко вводили биодобавку (по 1 мл/кг живой массы), количество которой корректировалось в зависимости от изменения живой массы. Кроме молочных кормов молодняку контрольной и опытной групп скармливали зерновую смесь из овса, пшеницы и кукурузы, люцерновое сено. Между двумя кормлениями выпаивали тёплую воду. Телята всех групп потребляли практически равное количество энергии, протеина, жира. Энергетическая питательность рационов всех групп была достаточно высокой. Концентрация обменной энергии в 1 кг сухого вещества составила 16,45-16,36 МДж.
Соотношение кальция к фосфору, а также сахаропротеиновое отношение были оптимальными.

При формировании групп живая масса подопытных телят была практически одинаковой. Но уже в месячном возрасте телята опытной группы по этому показателю превосходили контрольных на 1,5 кг, а в 2-месячном возрасте - на 4,1 кг, или на 5,3\% (табл. 2).

В целом за период опытные телята превосходили контрольных по валовому приросту на 8,1\%. Затраты ЭКЕ на 1 кг прироста у телят в контрольной группе составили 3,5, а в опытной - 3,28, или на 6,3\% меньше. 
Таблица 2 - Изменение живой массы и среднесуточного прироста телят

\begin{tabular}{|l|c|c|}
\hline \multicolumn{1}{|c|}{ Ингредиенты } & \multicolumn{2}{|c|}{ Группа } \\
\cline { 2 - 3 } & контрольная & опытная \\
\hline $\begin{array}{l}\text { Живая масса, кг: } \\
\text { - при постановке на опыт }\end{array}$ & $34,4+0,51$ & $35,0+0,54$ \\
\hline - в 1 месяц & $55,7+0,43$ & $82,46+0,52$ \\
\hline - в 2 месяца & $78,3+0,49$ & $47,46+0,4$ \\
\hline Валовой прирост за период, кг & $43,9+0,18$ \\
\hline + к контролю, \% & - & 8,1 \\
\hline $\begin{array}{l}\text { Среднесуточный прирост, г: } \\
\text { - за 1-й месяц }\end{array}$ & $710+7,0$ & $740+4,8$ \\
\hline - за 2-й месяц & $753+5,5$ & $842+5,8$ \\
\hline Среднесуточный прирост за период, г & $732+8,0$ & $791+9,0$ \\
\hline + к контролю, \% & - & 8,0 \\
\hline
\end{tabular}

Показатели относительной скорости и коэффициенты роста подопытных телят приведены в таблице 3.

Рост телят протекал с закономерно постоянно уменьшающейся скоростью, причём у молодняка опытной группы по отношению к контрольным животным на протяжении всего периода относительная скорость роста была несколько выше, что свидетельствует о большей интенсивности обмена веществ у опытного поголовья. Животные в опытной группе болели на $13 \%$ меньше по сравнению с контрольными. При клиническом осмотре у телят отмечали повышенную секрецию слизистой оболочки носовой полости, кашель. В дальнейшем, по мере применения терапевтических средств, эти явления стабилизировались. Следует отметить, что респираторные заболевания молодняка контрольной группы, по сравнению с животными опытной группы, были более выражены. Желудочно-кишечных заболеваний телят в опытной группе, по сравнению с контрольными, было меньше на 27\%. О6щая продолжительность болезней у животных контрольной группы составила 51 сутки, у телят опытной - 17 суток. Видимо, сказалось влияние условно-патогенной микрофлоры на животных с пониженной резистентностью в первые дни выращивания.

В результате биохимических исследований крови телят в возрасте 2-х месяцев установлено, что у подопытных животных изучаемые биохимические показатели находились в пределах физиологической нормы. Показатели фракционного состава сывороточных белков крови у телят опытной группы в 2-месячном возрасте несколько отличались от контрольных по содержанию альбуминов и глобулинов. Так, содержание альбуминов и глобулинов в крови телят опытной группы было больше, чем в контроле на 2,65 и 6,04\% соответственно. Уровень белкового индекса (А/Г коэффициента) был достаточно высоким у телят обеих групп, что свидетельствует об интенсивном белковом обмене. Количество гемоглобина в крови у телят опытной группы было больше контрольных на 2,53\%. Также у них было больше (на 10\%) количество эритроцитов в крови. Насыщенность эритроцитов гемоглобином была выше у опытных животных, по сравнению с контролем, на 21,0\%. Содержание общего кальция и неорганического фосфора у телят опытной группы было выше контрольных, особенно фосфора (до 15\%). Содержание общего кальция у всех животных

Таблица 3 - Интенсивность роста телят

\begin{tabular}{|c|c|c|c|c|}
\hline \multirow{2}{*}{ Возраст, мес. } & \multicolumn{2}{|c|}{ Относительная скорость роста, \% } & \multicolumn{2}{c|}{ Коэффициент роста } \\
\cline { 2 - 5 } & контрольная & опытная (+/- к контролю) & контрольная & опытная (+/- к контролю) \\
\hline $0-1$ & 47,28 & $48,15(+0,870)$ & 1,62 & $1,63(+0,010)$ \\
\hline $1-2$ & 33,73 & $36,17(+2,440)$ & 2,27 & $2,36(+0,086)$ \\
\hline
\end{tabular}


имело нормальное значение, что говорит о сбалансированности рационов по этому элементу. Что касается неорганического фосфора, то его повышенное содержание в крови у телят опытной группы служит косвенным доказательством улучшения белкового обмена в организме телят, потреблявших биодобавку.

Для изучения влияния биодобавки на состав и концентрацию микрофлоры желудочно-кишечного тракта телят были исследованы образцы кала животных в 2-месячном возрасте. В результате установлено, что состав микрофлоры у обеих групп животных находился в пределах нормы. Наблюдается некоторое снижение у животных опытной группы по отношению к контролю стафилококков и дрожжеподобных грибов. Клостридии и другие условно-патогенные энтеробактерии в исследуемых образцах кала не обнаруживались.

По результатам опыта была рассчитана экономическая эффективность выращивания телят, которая показала, что в опытной группе телят получено больше валового прироста на 3,56 кг от каждого животного по сравнению с контролем
(+8,11\%). Дополнительный доход от условной реализации каждого животного опытной группы, по нашим расчётам, был на 230 руб. больше по сравнению с доходом от реализации телят контрольной группы.

\section{Bывод}

Применение в рационах телят биологически активной добавки на основе гидроксид полимальтозных хелатных комплексов и микроэлементов меди, кобальта, селена, йода, марганца в виде амминоатов, цинка в хелатной форме глюконата, а также гидролизата растительного белка оказало положительное действие на организм в целом, функции различных органов и систем животных. В целом за период исследования опытные телята превосходили контрольных по валовому приросту на 8,11\%.

Таким образом, технология кормления молодняка крупного рогатого скота на основе оптимизации рационов с применением отечественной кормовой добавки, обладающей высокими биологическими свойствами, изготовленной из недорогих видов сырья, позволила обеспечить высокую интенсивность роста телят.

\section{Лumepamypa}

1. Кальницкий, Б.Д. Биологическая доступность минеральных веществ и обеспечение ими животных [Текст] / Б.Д. Кальницкий // Сельское хозяйство за рубежом. - 1979. - № 7. - С. 32.

2. Самохин, В.Т. Профилактика нарушений обмена микроэлементов у животных [Текст] / В.Т. Самохин. - 2-е изд., исправ. и доп. - Воронеж: Воронежский государственный университет, 2003. - 136 с.

3. Френк, А.М. Инновационность использования в комбикормовой промышленности гидролизатов растительного белка и микроэлементных препаратов производства ООО Фирма «А-Био» [Текст] / А.М. Френк // Сборник научных трудов МПА. - Выпуск ХІ. - М., 2013. - С. 58-64.

4. Бетин, А.Н. Эффективность применения Абиопептида и Биожелеза в рационах цыплят-бройлеров [Текст] / А.Н. Бетин, А.И. Фролов, В.Ю. Лобков // Вестник АПК Верхневолжья. - 2014. - № 4 (28). - С. $50-53$.

5. Захаров, В.А. Эффективность использования биологически активных добавок в кормлении подсосных свиноматок и поросят [Текст] / В.А. Захаров, А.Н. Бетин, Е.В. Слотина // Вестник Рязанского государственного агротехнологического университета им. П.А. Костычева. - 2015. - № 1 (25). - С. $23-27$.

6. Викторов, П.И. Методика и организация зоотехнических опытов [Текст]: метод. пособие для высш. с.-х. учеб. заведений / П.И. Викторов, В.К. Менькин. - М.: Агропромиздат, 1991. - 110 с.

7. Калашников, А.П. Нормы и рационы кормления сельскохозяйственных животных [Текст] / А.П. Калашников, В.И. Фисин и др. - М., 2003. - 456 с.

\section{References}

1. Kal'nickij, B.D. Biologicheskaja dostupnost' mineral'nyh veshhestv i obespechenie imi zhivotnyh [Tekst] / B.D. Kal'nickij // Sel'skoe hozjajstvo za rubezhom. - 1979. - № 7. - S. 32.

2. Samokhin, V.T. Profilaktika narushenij obmena mikrojelementov u zhivotnyh [Tekst] / V.T. Samokhin; 2-e izd., isprav. i dop. - Voronezh: Voronezhskij gosudarstvennyj universitet, 2003. - $136 \mathrm{~s}$.

3. Frenk, A.M. Innovacionnost' ispol'zovanija v kombikormovoj promyshlennosti gidrolizatov rastitel'nogo belka i mikrojelementnyh preparatov proizvodstva OOO Firma «A-Bio» [Tekst] / A.M. Frenk // Sbornik nauchnyh trudov MPA. - Vypusk XI. - M., 2013. - S. 58-64.

4. Betin, A.N. Jeffektivnost' primenenija Abiopeptida i Biozheleza v racionah cypljat-brojlerov [Tekst] / A.N. Betin, A.I. Frolov, V.Yu. Lobkov // Vestnik APK Verhnevolzh'ja. - 2014. - № 4 (28). - S. 50-53. 
5. Zakharov, V.A. Jeffektivnost' ispol'zovanija biologicheski aktivnyh dobavok v kormlenii podsosnyh svinomatok i porosjat [Tekst] / V.A. Zakharov, A.N. Betin, E.V. Slotina // Vestnik Rjazanskogo gosudarstvennogo agrotehnologicheskogo universiteta im. P.A. Kostycheva. - 2015. - № 1 (25). - S. $23-27$.

6. Viktorov, P.I. Metodika i organizacija zootehnicheskih opytov [Tekst]: metod. posobie dlja vyssh. s.-h. ucheb. zavedenij / P.I. Viktorov, V.K. Men'kin. - M.: Agropromizdat, 1991. - 110 s.

7. Kalashnikov, A.P. Normy i raciony kormlenija sel'skohozjajstvennyh zhivotnyh [Tekst] / A.P. Kalashnikov, V.I. Fisin i dr. - M., 2003. -456 s.

\title{
ОБЫЯВЛЕНИЕ
}

\section{В издательстве ФГБОУ ВО Ярославская ГСХА в 2018 году вышла монография \\ Л.П. МОСКАЛЕНКО, Н.С. ФУРАЕВОЙ, Е.А. ЗВЕРЕВОЙ, Н.А. МУРАВЬЕВОЙ \\ «СОВЕРШЕНСТВОВАНИЕ МЕТОДОВ РАЗВЕДЕНИЯ МОЛОЧНЫХ ПОРОД КРУПНОГО РОГАТОГО СКОТА»}

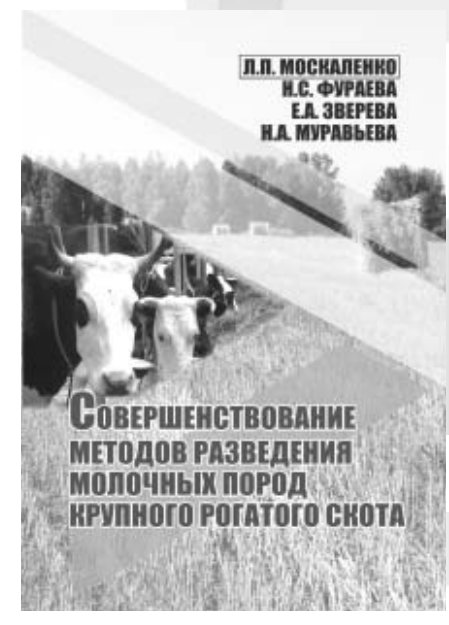

Авторами рассмотрено состояние молочного скотоводства в Ярославской области, исследована и обобщена эффективность использования голштинской породы для совершенствования племенных и продуктивных качеств животных, изучена и усовершенствована генеалогическая структура молочных пород скота, установлены факторы, влияющие на молочную продуктивность активной части популяции.

Монография предназначена для научных работников, аспирантов и студентов высших сельскохозяйственных учебных заведений, специалистов агропромышленного комплекса.

\section{УДК 636.2.084.1; ББК 45.3; ISВN 978-5-98914-206-4; 304 стр.}

ПО ВОПРОСАМ ПРИОБРЕТЕНИЯ ОБРАЩАТЬСЯ ПО АДРЕСУ: 150042, г. Ярославль, Тутаевское шоссе, 58, ФГБОУ ВО Ярославская ГСХА

\author{
e-mail: e.bogoslovskaya@yarcx.ru
}

